\title{
DISCRIMINATION AGAINST WOMEN IN TURKISH LABOR MARKET: AN ANALYSIS OF GENDER WAGE GAP WITH BLINDER-OAXACA AND JUHN-MURPHY-PIERCE DECOMPOSITION METHODS, 2004-2017 PERIOD
}

DOI: 10.17261/Pressacademia.2018.1002

JEFA- V.5-ISS.4-2018(4)-p.349-358

Taylan Akgul

Anadolu University, Department of Labor Economics and Industrial Relations, Yunus Emre Campus, Eskisehir, Turkey. takgul@anadolu.edu.tr, ORCID: 0000-0003-0753-8615

Date Received: October 26, 2018

Date Accepted: December 17, 2018

To cite this document

Akgul, T. (2018). Discrimination against women in Turkish labor market: an analysis of gender wage gap with Blinder-Oaxaca and JuhnMurphy-Pierce decomposition methods, 2004-2017 period. Journal of Economics, Finance and Accounting (JEFA), V.5(4), p.349-358.

Permemant link to this document: $\underline{\text { http://doi.org/10.17261/Pressacademia.2018.1002 }}$

Copyright: Published by PressAcademia and limited licenced re-use rights only.

\begin{abstract}
Purpose - The average education level of female in the labor force is higher than the education level of their male counterparts in Turkey. Since education level is the most important factor in the determination of wages, the average wage of female employees is expected to be higher than that of male employees. However, the data shows the reverse. In this paper, the gender wage gap in the 2004-2017 period is analyzed to understand what portion of the wage gap is due to discrimination and what portion is due to human capital factors. The sample used in the econometric analysis is the Household Labor Force Survey microdata in the 2004-2017 period. Blinder-Oaxaca and JuhnMurphy-Pierce Decomposition methods are applied, and the results show that the gender wage gap in favor of male employees in the said period cannot be explained by human capital differences, but by discrimination against women in the labor market.

Methodology - First wage equation regressions are set to see whether there is a difference between the effects and significance of explanatory variables on wages of male employees and females. Then, Blinder Oaxaca and Juhn Murphy Pierce decomposition methods are applied to see whether the wage gap can be explained by human capital differences or not.

Findings- Data shows that there is a gender wage gap in favor of men in Turkish labor market and a strong discrimination against women. As for 2004 , considering the human capital endowments, on average, women would have earned $5.2 \%$ more than what male employees earn. However, data show that male employees earn $15.1 \%$ more than what female employees earn, which can be interpreted that female employees have a wage-loss of about $20.3 \%$ due to discrimination. Both the wage gap and discrimination effects vary between regions. Most industrialized/developed and regions with high agriculture share in employment are usually the ones with larger gap and higher degree of discrimination. The wage gap and discrimination effects have declined until 2010, but they increased after that.

Conclusion- Gender wage gap and discrimination based loss in wages are seem to be persistent so far in Turkish labor market, but as the average level of female employees increase the gap is expected to decline in long run.
\end{abstract}

Keywords: Gender wage gap, labor force surveys, micro data, Blinder Oaxaca Decomposition, Juhn-Murphy-Pierce Decompositon JEL Codes: J14, J16, J31

\section{INTRODUCTION}

Gender is an important factor that affects labor force participation and wages. In general, it is a known fact that women's labor force participation rate is significantly lower than that of men in all regions especially in underdeveloped and developing countries. In addition, the unemployment rate for women is higher in the less developed regions compared to the developed regions.

As can be seen from Table 1 below, the labor force participation of adult males varies between $72 \%$ and $87 \%$ in the world, while it is below $60 \%$ for adult females, and is even lower in the Arab States. The Arab States is also the worst region with regard to the youth female labor force participation rate, which is only $13.5 \%$. Also, it's obvious from the table that young people's (15-24 years) labor force participation is lower than that of older adults in all regions. 
Table Hata! Belgede belirtilen stilde metne rastlanmadı.: Labor Force Participation Rates by Age and Gender

\begin{tabular}{lllclllc}
\hline Region & Gender & $\begin{array}{l}\text { Age } \\
\text { Group }\end{array}$ & $\begin{array}{c}\text { Labor Force } \\
\text { Participation } \\
\text { (\%) }\end{array}$ & Region & Gender & $\begin{array}{l}\text { Age } \\
\text { Group }\end{array}$ & $\begin{array}{c}\text { Labor Force } \\
\text { Participation } \\
\text { (\%) }\end{array}$ \\
\hline Developed Countries & Male & Youth & 47.1 & Latin America & Male & Youth & 59 \\
Developed Countries & Male & Adult & 72.4 & Latin America & Male & Adult & 84.3 \\
Developed Countries & Female & Youth & 41.4 & Latin America & Female & Youth & 39.9 \\
Developed Countries & Female & Adult & 54.1 & Latin America & Female & Adult & 56.2 \\
Eastern Europe & Male & Youth & 40.1 & Arab States & Male & Youth & 45.9 \\
Eastern Europe & Male & Adult & 72.4 & Arab States & Male & Adult & 87 \\
Eastern Europe & Female & Youth & 31 & Arab States & Female & Youth & 13.5 \\
Eastern Europe & Female & Adult & 55.7 & Arab States & Female & Adult & 24.5 \\
Eastern Asia & Male & Youth & 52.3 & Eastern Asia & Female & Youth & 50.6 \\
Eastern Asia & Male & Adult & 80.9 & Eastern Asia & Female & Adult & 63 \\
\hline SOurc: & & & & & & & \\
\hline
\end{tabular}

Source: 2017 ILO estimates.

Table 2, which is compiled from the International Labor Organization (ILO) data, provides unemployment rates for women and men in various regions of the world. Accordingly, it is observed that in all regions, except Latin America and the Arab States, the female unemployment rate is a little above that of men. Asia is notable for the fact that women's labor force participation is higher and the unemployment rate is lower. Latin America is noteworthy due to the comparatively low women labor force participation and the relatively high female unemployment rate.

Table 2: Unemployment Rates by Gender

\begin{tabular}{lll}
\hline Country Group & Gender & Unemployment (\%) \\
\hline Low Income & Male & 4.6 \\
Low Income & Female & 6.2 \\
High Income & Male & 5.3 \\
High Income & Female & 5.9 \\
Asia & Male & 4 \\
Asia & Female & 4.1 \\
Latin America & Male & 7.2 \\
Latin America & Female & 9.8 \\
Arab States & Male & 6.1 \\
Arab States & Female & 17.1 \\
Europe & Male & 8.2 \\
Europe & Female & 8.6 \\
\hline Sourc: $2017 !$ estimates. & &
\end{tabular}

Source: 2017 ILO estimates.

\section{LITERATURE REVIEW}

The difference in male-female wage emerged with the emergence of paid female labor. In the early stages of the Industrial Revolution, the wage was based on more work per piece rather than hourly work. In a study which examined the records of labor costs in various cities in England between 1750 and 1842, it was determined that the ratio of payments made per woman to men was between 0.33 and 0.75 (Burnette, 1997, pp. 258-260). In the hourly wage payment, it is difficult to determine how much of the wage difference between men and women originate from gender-based discrimination. However, no difference in productivity can be mentioned in the price per piece, since the work unit or the product produced is the same. For this reason, it can be argued that the difference in wage per piece is caused by discrimination based on gender.

Today, the daily wage system is implemented in Turkey especially in agricultural sector, and both seasonal and permanent agricultural female workers are paid lower wages. According to statistics from TURKSTAT, daily payment to seasonal agricultural workers was $41 \mathrm{TL}$ for female workers and $54 \mathrm{TL}$ for males. Considering the monthly payments for permanent workers, $1118 \mathrm{TL}$ was paid to women and $1304 \mathrm{TL}$ to men (Tarımsal İşletmelerde Ücret Yapısı, Wage Structure in Agricultural Enterprises, 2014). These data show that there is a $24 \%$ wage gap between men and women in daily wage earners and $14 \%$ gap in monthly wages.

Why men earn higher wages than women is a matter of debate. Although there are many sociological, legislative and economic reasons, the question that is being sought in econometric studies is the following: Does the wage gap occur due to the differences in endowments (such as education, experience, skills) or the gap is caused by different marginal effects of these endowments, which indicates a discrimination? In other words, although the marginal effect of explanatory variables 
such as educational experience is the same for men and women, do women have lower human capital and therefore receive lower wages because there are more frequent interruptions in women's work and education life due to reasons such as childcare and marriage, or do the employers pay less to women for the same endowments?

In order to analyze whether there is a difference between the determinants of wages of black and white men and women, the microdata on wages in the 1976-1985 period was used in a research conducted by Wellingon in 1993. The study shows that there is no significant difference between the effect of education and experience on wages among men and women. However, it was found that men could devote more time to work-related training and eventually receive higher wages. It was also stated in the study that women work more in part-time jobs than men in their lives, and this situation makes men more advantageous in terms of work experience (Wellington, 1993, p. 404).

Indeed, the part-time employment rate among women as well as the share of women in part-time employment is high in all countries. Table 3 compiled using ILO data confirms this. In all selected countries with different levels of development, the rate of part-time employment in women is much higher than that of men. Another striking point in the table is the fact that the share of women in part-time employment is higher in developed countries compared to developing countries such as Turkey, Mexico and Argentina.

Table 3: Part-Time Employment

\begin{tabular}{|c|c|c|c|c|c|}
\hline \multirow[b]{2}{*}{ Country } & \multirow[b]{2}{*}{ Year } & \multicolumn{2}{|c|}{ Part-time Employment Rates } & \multirow[b]{2}{*}{ Year } & \multirow{2}{*}{$\begin{array}{c}\text { Women Share of Part-time } \\
\text { Employment }\end{array}$} \\
\hline & & Male & Female & & \\
\hline Argentina & 2017 & 16.0 & 34.8 & 2012 & 62.8 \\
\hline Canada & 2017 & 15.9 & 27.9 & 2014 & 66.6 \\
\hline France & 2014 & 13.5 & 26.4 & 2014 & 78.6 \\
\hline Germany & 2017 & 10.9 & 33.6 & 2014 & 78.1 \\
\hline Israel & 2015 & 14.6 & 28.7 & 2014 & 69.4 \\
\hline Italy & 2017 & 10.0 & 31.3 & 2014 & 73.9 \\
\hline Japan & 2015 & 11.7 & 35.6 & 2014 & 69.8 \\
\hline Mexico & 2017 & 12.6 & 26.6 & 2014 & 56.8 \\
\hline Switzerland & 2017 & 13.0 & 37.3 & 2014 & 78.5 \\
\hline Turkey & 2017 & 8.6 & 21.4 & 2014 & 57.7 \\
\hline
\end{tabular}

Source: ILO database.

There are also studies claiming that the effect of education on wages differ between men and women. In a paper consisting of female and male high college graduates, high school graduates and those who have not completed their high school education, $5 \%$ of the 1990 US surveys were used as a sample and the result shows that contribution of education on wages differ for all education levels between the two genders. According to the findings, the wage difference between college graduate and high school graduate men is $73.6 \%$ and this difference is about $80 \%$ in women (McCall, 2000, pp. 244-245). In other words, the effect of education on wages is more pronounced in women. In the same study, differences were found between the men and women in terms of the effect of education level on employment rate. According to the results of the study, it was found that the probability of finding a job for a woman with a college degree was $16 \%$ higher than that of a high school graduate. (McCall, 2000, p. 248) When these two results are evaluated together, it can be said that the effect of education on both job finding and wage is much stronger for women compared to men.

It is known that in Turkey, the effect of university education on the labor force participation rate is stronger for women compared to that of men. As it can be seen from Table 4, compiled using 2015 TurkStat data, while the labor force participation rate of male high school graduates was $73 \%$, it was $89.4 \%$ for university graduates. In contrast, the labor force participation rate of female high school graduates was $33.3 \%$ and $72.9 \%$ for university graduates (TURKSTAT, 2016). In other words, university graduation leads to an increase of 16.4 points in the labor force participation of men and 39.6 points in that of women. As can be seen from the table, as the level of education increases, the difference between female and male participation rates decreases. Another remarkable fact is that the female labor force participation rate of university graduates is 3 percentage points lower than the participation rate of the illiterate but uneducated men. The conclusion to be drawn from this table is that the most effective way to increase the female labor force participation rate is to establish policies to increase the number of women with tertiary education. 
Table 4: Labor Force Participation Rates of Women and Men by Education Levels (\%)

\begin{tabular}{lll}
\hline Education Level & Erkek & Kadın \\
\hline Illiterate & 46,5 & 22,9 \\
Literate but No Diploma & 75,9 & 25,3 \\
Primary School Graduate & 79,7 & 31,2 \\
Secondary School Graduate & 63,6 & 21 \\
High School Graduate & 73 & 33,3 \\
Vocational High School Graduate & 82,9 & 42,1 \\
University Graduate & 89,4 & 72,9 \\
\hline
\end{tabular}

Source: 2015 TURKSTAT Micro Data

In an interesting study on the wage gap between men and women (Filer, 1985, p. 427), it was suggested that the wage difference cannot only be explained by gender as there is a number of other factors that should be taken into account. According to the so-called "Compensating differentials" explanation, factors such as the risk of the job, the responsibilities it entails, and the autonomy it requires can lead to more compensation payment in some jobs and there are differences in the choices of men and women. This compensation is one of the reasons why men are paid more. For example, secure work may be more preferable for women, whereas men may not pay similar attention to job security and as a result, men who work in more precarious jobs may receive higher wages as compensation.

A study similar to the work of Filer was conducted on the Spanish labor market. In this study; different from Filer, variables such as the size of the workplace (number of employees), type of market addressed by the firm (national, international) and type of employment contract (part-time, continuous, fixed time etc.) were taken into account. It was proposed that the explanatory variables such as whether it was subject to collective bargaining and the degree of skills or qualifications required by the job (high, medium, weak) had an effect on wages, and that there were differences in terms of employment among men and women in such jobs, and the wage difference was partly due to these job-specific properties (Polavieja, 2005, pp. 168-169). In his model, Polajeva tried to analyze how much of the variance in wages could be explained by workspecific variables and how much of the variance could be explained by other variables such as human capital factors.

In the context of Polavieja's work, two separate models, one composed just of human capital data and the other consisting of the work specific variables in addition to the human capital variables, were tested. According to the findings of the study, the gender wage gap was $22.7 \%$ in the model where only human capital was used, and only $16 \%$ of this gap could be explained by individual human capital (education, age) differences. In the second model using work-specific variables, the wage difference fell to 14.8 points and the remaining difference was due to work-specific variables (Polavieja, 2005, p. 174). When the studies by Filer and Polajeva are evaluated together, it can be seen that the difference in the wages between men and women is not only the result of gender-based discrimination or human capital differences between men and women, but also of the nature of work (risk, autonomy, responsibility, etc.) and work-related legal and technical characteristics (workplace size, market type, the degree of qualification required by the job).

It is also suggested that women's lower wages are not due to lower paid jobs and sectors, but rather to discrimination of male managers against female employees. Local industries wage data from various states of USA was used in a study which tested the hypothesis that "as the weight of women in managing positions increases, the gender wage gap among employees decreases". In the study, it was determined that the increase in female ratio among managers reduced the difference in wages, and the increase in female managers' positions further strengthened this effect (Cohen and Huffman, 2007, p. 698).

Swedish banking sector wage data was used in another study that supports the thesis that lower wages of women do not result from the difference in employment or sector. It was found that the wage gap was reduced in the banking sector with the effect of the trade unions before 1980, but it increased again after 1983. It was emphasized that the gender wage gap can be reduced only if the share of collective bargaining increases and the share of the individual employment contracts decreases (Acker, 1991, p. 405).

It is a known fact that social policies towards women are an important factor in making decisions such as withdrawal from the labor market or transition to part-time work. Factors such as child benefit, length of paid leave and payment amount are undoubtedly affecting women's planning of work life. The labor force participation rates of women in the Scandinavian countries and other parts of the world where women's social policies are highly developed are significantly higher. The labor force participation of women in the world is around 50 percent while the average is 53 percent in the developed economies and in the EU. This ratio is about $85-88 \%$ in the Scandinavian countries.

In a study analyzing the effects of variables such as education, work experience, trade union membership, small child ownership, residence in the big city and housework on wages, it was found that the effects of many explanatory variables differ between men and women. In this study, using the data set of the Panel Study of Income Dynamics 1979-1987 by the 
University of Michigan, it was found that the variable "doing housework" has a negative and significant effect on wages for both men and women but the effect on women wages was twice that of men (Hersch and Stratton, 1997, p. 291). Both childcare and domestic work, both of which are time-consuming (especially in women) and therefore negatively impacting human capital and productivity, had a negative impact on wages. The time spent on childcare or housework can alternatively be spent on individual's self-development and attendance. In addition, both childcare and housework require significant energy and they cause an increase in the level of anxiety. Both the energy devoted to housework and childcare and the increase in anxiety level affect productivity negatively, which is reflected in the wage because the wages under the market conditions are paid according to efficiency.

It is also debated whether gender-based wage gap varies among industries (service, industry and agriculture) or public and private sectors. Since the employment in the public sector is subject to more stringent regulations, it is expected that the difference in wages between men and women in the public sector will be lower than that in the private sector. It is known that in Turkey and in many developing countries, the gender wage gap is higher in the agricultural compared to the service and industrial sectors. In a study using Danish labor market data between 1980 and 1990, gender-based wage gap in public and private sectors was examined according to qualification levels, and, as expected, the wage gap in the private sector was found to be wider (Rosholm and Smith, 1996, p. 267). In 1980, among qualified employees, the gender wage gap was $23 \%$ in public sector, while it was $33 \%$ in private sector. Among the non-qualified employees, the gender wage gap was $17 \%$ in the private and $10 \%$ in public sector. In 1990, the gender wage gap among qualified employees decreased to $18 \%$ and to $9 \%$ among nonqualified employees in the public sector. As for the private sector, the gender wage gap reduced to $30 \%$ among qualified employees while it increased to $18 \%$ among nonqualified employees (Rosholm and Smith, 1996, p. 297). The higher gender wage gap among qualified employees can be read as an indicator of the higher effect of education on wage is higher in men. Indeed, Kumlin (2007) reported that the difference between men and women regarding the effect of education on wages is higher in Japan compared with Sweden

Another factor that affects the gender wage gap is marital status. If the average age (and hence the work experience) is higher, the married people are expected to be paid higher wages than their wives because of the higher number of booking fees due to childcare. In addition, the average wage income is expected to be lower than the married ones because the widows are generally elderly. To compare the wages of those who are married to those who are married, the average age of the divorced is difficult to determine without knowing the average age of those who are married. On the other hand, if the divorced couple has children, it is also important to consider which one of the parties takes child care. The party caring for the child will naturally agree to work with higher wages. For this reason, it is impossible to estimate the wages of divorced people as a priori.

\section{DATA AND METHODOLOGY}

\subsection{Data}

Turkish Household Labor Force Survey's microdata for the 2004-2017 period is used in this paper. Household Labor Force Survey being implemented regularly since 1988 by Turkish Statistical Institute, is the main data source which provides information about those employed; economic activity, occupation, employment status, wages, working hours etc. Also, for the unemployed, the survey contains information on job search time and search channels. All private households who are living in the territory of the Republic of Turkey are covered. Residents of schools, dormitories, kindergartens, rest homes for elderly persons, special hospitals, military barracks and recreation quarters for officers are not covered. Data are collected from the households which are selected by the defined sampling method. Statistical unit used is "household" in labor force surveys. Demographic information (age, sex, educational status, relationship to household head) is asked to all members of the household. But, questions on labor force status are asked for persons 15 years old and over. All information is collected by interviewers on a face-to-face basis with the help of portable computers (Computer Assisted Personal InterviewingCAPI).

\subsection{Model and Method}

Blinder-Oaxaca decomposition is an important method for analyzing the difference in wages of men and women. In the absence of discrimination in the labor market, men and women should get same wages if they have the same endowments (such as human capital, age, work experience, sector of employment, marital status etc). In other words, people who have the same characteristics except for their gender, should receive equal pay. In practice, however, the situation is different. As it can be seen from the regression results of this study, while all other variables are the same, there are statistically significant wage differences due to gender.

In this context, a method was suggested by Blinder (1973) and Oaxaca (1973) to analyze what portion of the wage gap can be explained by the variables such as education, age, experience, sector and what portion can not be explained by these 
factors. The method basically reveals how much of the wage gap can be explained by objective independent variables for two different groups and how much of the gap can't be explained by these parameters.

Let's assume that wage equations for male (1) and female (2) employees are:

$$
\begin{gathered}
\operatorname{Ln} W^{M}=\gamma_{M}+\delta_{M} A_{M}+\varepsilon \\
L n W^{F}=\gamma_{F}+\delta_{F} A_{F}+\mu
\end{gathered}
$$

Here $L n W^{M}$ and $L n W^{F}$ represents the logarithmic values of male and female employees' wages respectively. $\gamma_{M}$ and $\gamma_{F}$ are the constant terms, $\delta_{M}$ and $\delta_{F}$ are explanatory variables coefficients vectors, $A_{M}$ and $A_{F}$ are explanatory variable vectors and $\varepsilon$ and $\mu$ are error terms for men and women respectively. If there is no difference or discrimination in the determination of wages of men and women, there should be no statistically significant difference between constant terms ( $\gamma_{M}$ and $\gamma_{F}$ ) and coefficient vectors $\delta_{M}$ and $\delta_{F}$.

A statistical difference between these coefficients would mean that the effect of the explanatory variables on wage differs between men and women. As can be seen in Table 5, which shows the results of the wage regressions given for the years 2004, 2010 and 2017 (in Equations 1 and 2) for the whole country, the effect of the explanatory variables on wage is different for male and female employees. The logarithm of wage is the dependent variable in the regression. Explanatory variables consist of demographics (age, square of age, household size, marital status), education (last diploma obtained) and sector (agriculture, services and industry) in which employee works. For marital status, being single is chosen as the base dummy and agriculture is chosen as the base dummy for sector while the absence of was chosen as the base dummy for education. Thus, coefficient "High School" shows the logarithmic wage difference between having a high school diploma and having no diploma, while all other factors are same.

\begin{tabular}{|c|c|c|c|c|c|c|c|c|c|}
\hline \multirow{2}{*}{$\begin{array}{l}\text { LnWage } \\
\text { Explanatory Variables }\end{array}$} & \multicolumn{3}{|c|}{2004} & \multicolumn{3}{|c|}{2010} & \multicolumn{3}{|c|}{2017} \\
\hline & Mixed & Male & Female & Mixed & Male & Female & Mixed & Male & Female \\
\hline \multicolumn{10}{|l|}{ Demographics } \\
\hline Age & 0.07 & 0.08 & 0.05 & 0.07 & 0.08 & 0.06 & 0.06 & 0.07 & 0.05 \\
\hline Age Squared & 0.00 & 0.00 & 0.00 & 0.00 & 0.00 & 0.00 & 0.00 & 0.00 & 0.00 \\
\hline Household Size & -0.01 & -0.02 & 0.00 & -0.01 & -0.02 & -0.01 & -0.02 & -0.02 & -0.03 \\
\hline Married & 0.12 & 0.13 & 0.01 & 0.13 & 0.13 & 0.05 & 0.09 & 0.12 & 0.04 \\
\hline Divorced & -0.04 & 0.03 & 0.04 & -0.01 & 0.00 & 0.10 & 0.01 & 0.03 & 0.07 \\
\hline Widowed & -0.15 & -0.10 & 0.02 & -0.21 & 0.01 & -0.09 & -0.08 & 0.05 & 0.00 \\
\hline \multicolumn{10}{|l|}{ Education } \\
\hline Primary School & 0.18 & 0.12 & 0.10 & 0.03 & 0.01 & -0.10 & 0.05 & -0.04 & 0.00 \\
\hline Secondary School & 0.28 & 0.21 & 0.28 & 0.17 & 0.13 & 0.16 & 0.23 & 0.10 & 0.19 \\
\hline High School & 0.52 & 0.44 & 0.63 & 0.34 & 0.28 & 0.42 & 0.34 & 0.21 & 0.39 \\
\hline Vocational High School & 0.53 & 0.44 & 0.66 & 0.37 & 0.30 & 0.47 & 0.38 & 0.23 & 0.45 \\
\hline University & 0.91 & 0.83 & 1.10 & 0.86 & 0.82 & 0.97 & 0.81 & 0.68 & 0.90 \\
\hline \multicolumn{10}{|l|}{ Sector } \\
\hline Industry & 0.49 & 0.43 & 0.43 & 0.42 & 0.33 & 0.44 & 0.23 & 0.23 & 0.15 \\
\hline Services & 0.48 & 0.43 & 0.43 & 0.40 & 0.32 & 0.41 & 0.19 & 0.22 & 0.12 \\
\hline Constant & 3.79 & 3.86 & 4.09 & 4.53 & 4.64 & 4.57 & 5.63 & 5.74 & 5.79 \\
\hline
\end{tabular}

Table 5: Wage Regression Results for Male, Female and Mixed Groups of Employees for Years 2004,2010 and 2017

Source: 2004, 2010 and 2017 Turkish Household Labor Force Survey microdata

The difference in the determination of wages between women and men raises the question of whether there is discrimination against women in the labor market. In fact, the difference in the effects of the explanatory variables that determine the wage is not a sufficient proof of discrimination. For this to be true, there should be a wage difference between the average wages of men and women with the same human capital. In other words, the wage difference has to be too large to be explained by the variables used in the model.

To reconcile, let's assume that education is the most important determinant of wage. If there is a gap between men and women in terms of the average level of education, the reason why men receive higher wages on average than women should be education, but not discrimination. On the other hand, if the wage gap is well above the size that can be explained by the educational difference, discrimination against women can be mentioned. For this to be determined, how much of the difference in wage is caused by the difference in explanatory variables should be calculated.

Using the wage equations (1) and (2) for male and female employees, the wage gap (WG) can be formulated as: 


$$
W G=\operatorname{Ln} W^{M}-\operatorname{Ln} W^{F}=\left(\gamma_{M}+\delta_{M} A_{M}+\varepsilon\right)-\left(\gamma_{F}+\delta_{F} A_{F}+\mu\right)
$$

In this case, the expected value of the wage gap can be formulated as:

$$
E(W G)=E\left(\operatorname{Ln} W^{M}\right)-E\left(\operatorname{Ln} W^{F}\right)=E\left(\gamma_{M}+\delta_{M} A_{M}+\varepsilon\right)-E\left(\gamma_{F}+\delta_{F} A_{F}+\mu\right)
$$

Since the expected values of the error terms is equal to zero $(\mathrm{E}(\varepsilon)=\mathrm{E}(\mu)=0)$ and the expected values of coefficients are equal to themselves $\left\{E\left(\gamma_{M}\right)=\gamma_{M}, E\left(\gamma_{F}\right)=\gamma_{F}, E\left(\delta_{M}\right)=\delta_{M} v e E\left(\delta_{F}\right)=\delta_{F}\right\}$, equation 4 can be rewritten as:

$$
E(W G)=\left(\gamma_{M}-\gamma_{F}\right)+\delta_{M} E\left(A_{M}\right)-\delta_{F} E\left(A_{F}\right)
$$

Equation 5 should be rewritten to illustrate the composition in the question so as to model how much of the wage differences between women and men are derived from human capital and other characteristics, and from how much discrimination originates. The method developed for this is that the coefficients in the wage equation of men are adapted to female wages (Daymont \& Andrisani, 1984, pp. 419-420). In this version, the question "what would the wage of women be if they had the same endowments as men" is answered. Thus, the algebraic notation will be:

$$
L n W_{F}^{*}=\gamma_{M}+\delta_{M} A_{F}+\mu
$$

In this hypothetical female wage equation, women's endowments $\left(A_{F}\right)$ are kept constant, and a hypothetical female wage $\left(L n W_{F}^{*}\right)$ is calculated by using explanatory variables coefficient vectors $\left(\gamma_{M}\right.$ ve $\left.\delta_{M}\right)$ of men.

Thus, it is possible to rewrite the wage difference between men and women (equation 3 ) as follows:

$$
\begin{aligned}
W G=\left\{\left(\gamma_{M}+\delta_{M} A_{M}+\varepsilon\right)-\left(\gamma_{M}+\delta_{M} A_{F}+\mu\right)\right\}+ & \left\{\left(\gamma_{M}+\delta_{M} A_{F}+\mu\right)-\left(\gamma_{F}+\delta_{F} A_{F}+\mu\right)\right\} \\
& =\left(\operatorname{Ln} W^{M}-L n W_{F}^{*}\right)+\left(L n W_{F}^{*}-\operatorname{Ln} W^{F}\right)
\end{aligned}
$$

Taking the expected values, the wage gap composition will finally be as follows:

$$
E(W G)=\overline{W G}=\left(\overline{\operatorname{Ln} W^{M}}-\overline{\operatorname{LnW_{F}^{*}}}\right)+\left(\overline{\operatorname{LnW_{F}^{*}}}-\overline{\operatorname{Ln} W^{F}}\right)
$$

Figure 1 geometrically illustrates the composition shown in the equation (8). Logarithms of wages are shown in $Y$-axis and endowments are shown in X-axis. $\left(\overline{\operatorname{Ln} W^{M}}-\overline{\operatorname{Ln} W_{F}^{*}}\right)$ reflects the gap between male and female wages due to the difference in endowments, and the second part $\left(\overline{\operatorname{LnW_{F}^{*}}}-\overline{\operatorname{Ln} W^{F}}\right)$ reflects the gap arising from the discrimination against women.

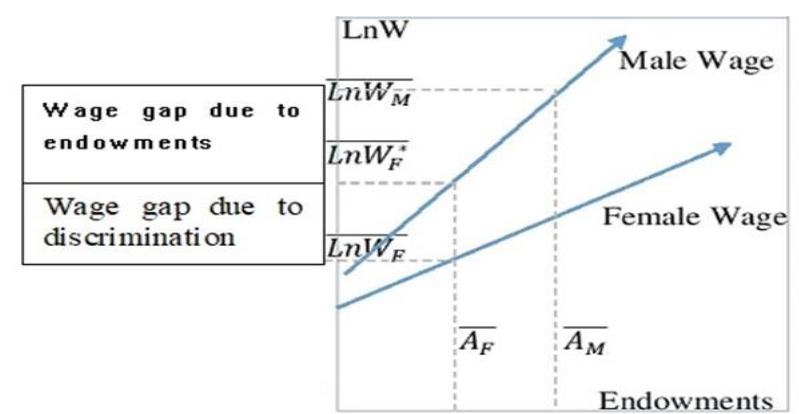

Figure 1: The wage gap due to endowments and discrimination against women

In this way, the amount of the difference in wages between males and females due to the difference in endowments could be calculated. The part of the wage gap which cannot be explained with endowment differences is considered to be caused by discrimination against women.

\section{FINDINGS AND DISCUSSIONS}

\subsection{Blinder-Oaxaca Decomposition}

Within the scope of this paper, the Blinder-Oaxaca decomposition was calculated using micro datasets with the STATA program for 12 regions (NUTS1) and the whole country for years 2004, 2010 and 2017. When the decomposition of 2004 for the country, as a whole, is considered, as it can be seen from Table 6 , there is a $15,1 \%$ wage gap in favor of men. If the women could get as much bonus as men to their endowments, the average wage of women would be $5.2 \%$ more than men. This is because the average education level of women in employment is higher than that of men. A significant proportion of the employed males are ones with low levels of education compared to the employed females where those with a high level of education have a higher weight in employment. In other words, the effect of education on labor force participation is much stronger in women. Therefore, despite the fact that the gap due to endowments should have been $5.2 \%$ in favor of 
women, the final difference was $15.1 \%$ in favor of men because of the $20.3 \%$ discrimination effect. This means that, on average, women are paid $20.3 \%$ less than what they could get if everything was fair.

Table 6: Blinder-Oaxaca Decomposition for Turkey, 2004

\begin{tabular}{lrrrrrr}
\hline LnWage & Coefficient & Standart E, & t-statistics & P>t & \% 95 Confidence Interval \\
Wage Gap & & & & & & \\
\hline Female & 5,920 & 0,007 & 793,470 & 0,000 & 5,906 & 5,935 \\
Male & 6,072 & 0,003 & 1872,360 & 0,000 & 6,065 & 6,078 \\
Difference & $-0,151$ & 0,008 & $-19,430$ & 0,000 & $-0,166$ & $-0,136$ \\
Decomposition & & & & & & \\
Explained & 0,052 & 0,004 & 11,810 & 0,000 & 0,043 & 0,061 \\
Unexplained & $-0,203$ & 0,007 & $-30,710$ & 0,000 & $-0,216$ & $-0,190$ \\
\hline
\end{tabular}

Source: Computed by using 2004 Household Labor Force Survey micro dataset

East Marmara (37.8\%), West Marmara (31.5\%) and Mediterranean (27.7\%) had the highest pay gap in 2004; the lowest regions were Southeast Anatolia (0.2\%), Middle East Anatolia (6.4\%) and Middle Anatolia (11.1\%). In other regions, the magnitude of discrimination-based gap varied between $11.3 \%$ and $26.4 \%$.

The final wage gap, despite the endowment-based gap (in favor of women) increased to $9.1 \%$ in 2010. Discrimination-based gap decreased to $18.2 \%$, on the other hand. This result shows that between 2004 and 2010, the proportion of educated women in employment increased. When we look at the absolute differences, it is possible to say that the discrimination against women decreased because both the final wage gap and discrimination-based gap decreased. On the other hand, it is possible to say that the discrimination against women increased because the ratio of the discrimination-based gap to the final gap rose. (since 18.2/9.1 is greater than 20.3/15.1)

Table 7: Blinder-Oaxaca Decomposition for Turkey, 2010

\begin{tabular}{lrrrrr}
\hline $\begin{array}{l}\text { LnWage } \\
\text { Wage Gap }\end{array}$ & Coefficient & Standard E, & t-statistics & P>t & \% 95 Confidence Interval \\
\hline Female & & & & \\
Male & 6.679 & 0.006 & 1150.850 & 0.000 & 6.667 \\
Difference & 6.770 & 0.003 & 2566.000 & 0.000 & 6.765 \\
Decomposition & -0.091 & 0.006 & -15.200 & 0.000 & -0.103 \\
Explained & & & & -0.079 \\
Unexplained & 0.091 & 0.004 & 23.840 & 0.000 & 0.083 \\
\hline
\end{tabular}

Source: Computed by using 2010 Household Labor Force Survey micro dataset

In 2010, the regions with the highest wage difference due to discrimination were Western Black Sea (29.3\%), West Marmara (26\%) and Mediterranean (25\%); the lowest regions were Northeast Anatolia (6.2\%), Southeast Anatolia (6.5\%) and Middle East Anatolia (7.5\%). In other regions, the wage difference from discrimination varied between $12.8 \%$ and $23.7 \%$.

In 2017, which is the last year of the examined period, both discrimination-based gap and the final gap were found to have risen again. As can be seen from Table 8, the final wage difference between men and women was $12.5 \%$ in favor of men and the wage difference caused by discrimination was $19.4 \%$ in favor of men. The wage difference in favor of women based on endowments decreased to $6.8 \%$ compared to 2010. In 2010 endowments-based gap was $9.1 \%$ in favor of women. These results show that the education premium in women's wages has decreased compared to 2010 and the discrimination has increased slightly.

Table 8: Blinder-Oaxaca Decomposition for Turkey, 2017

\begin{tabular}{|c|c|c|c|c|c|c|}
\hline $\begin{array}{l}\text { LnWage } \\
\text { Wage Gap }\end{array}$ & Coefficient & Standard E, & t-statistics & $P>t$ & \multicolumn{2}{|c|}{$\% 95$ Confidence Interval } \\
\hline Female & 7.436 & 0.005 & 1573.760 & 0.000 & 7.427 & 7.445 \\
\hline Male & 7.561 & 0.003 & 2987.660 & 0.000 & 7.556 & 7.566 \\
\hline Difference & -0.125 & 0.005 & -25.290 & 0.000 & -0.135 & -0.115 \\
\hline \multicolumn{7}{|c|}{ Decomposition } \\
\hline Explained & 0.068 & 0.003 & 22.410 & 0.000 & 0.062 & 0.074 \\
\hline Unexplained & -0.194 & 0.004 & -47.830 & 0.000 & -0.202 & -0.186 \\
\hline
\end{tabular}

Source: Computed by using 2010 Household Labor Force Survey micro dataset 
Considering the regional results of 2017, the highest wage gap due to discrimination was observed in Western Anatolia (28.3\%), Mediterranean (25.3\%) and Northeast Anatolia (24.1\%); the lowest regions were Southeast Anatolia (13.3\%), Eastern Black Sea (16.9\%) and Istanbul (16.4\%). In other regions, the wage difference from discrimination varied between $18.6 \%$ and $23.6 \%$.

\subsection{Juhn-Murphy-Pierce Decomposition}

The Blinder-Oaxaca method has been criticized for being static (Pereira and Galepo, 2007, p.3). A dynamic model showing the course of discrimination over time was proposed by Juhn et al. In a study in which the wage data of black and whites were examined in the 1963-1987 period, Juhn and others, who wanted to examine how much of the wage differences were caused by unobservable factors and the progress of this composition over time, used a dynamic econometric model (Juhn et al., 1991, pp. 122-126). Thus, it was possible to demonstrate the extent to which the change in endowments explained the change in wage differences. Juhn and others have now defined the difference in wages that cannot be explained by the change in endowments as residual differences. In a study conducted in 1993 by the same authors, they examined the effect of the increase in quality of skill on the wage differences by using the same econometric method. In the studies which examined the wage differences between the sectoral and vocational men in the agricultural, construction, manufacturing, retail and service sectors, they concluded that the difference due to the observed quality premium was insufficient to explain the difference between the sectors and the occupational groups (Juhn et al., 1993, p. 441).

Following the method of Juhn and others, in order to analyze the course of wage gap in the 2004-2017 period, educational status, age, square of age, marital status, sector of employment and urban residence were used as explanatory variables for the wage equations of men and women and course of wage gap is analyzed by the help of STATA statistics software by using the "jmpierce2" command.

In Juhn-Murhphy-Pierce (JMP) decomposition, it is possible to see the raw differences between wages, the differences due to the quantitative effect (weight in the labor market), residual differences and the change of these variables over time. Results of JMP decomposition are given in Table 9 and 10. To explain the concepts in the tables; the raw difference is the observed gap. The raw difference can be defined as the gap which occurs in the labor market when the wages, endowments of the workforce and the market price of these endowments are given. The residual difference, on the other hand, is the gap caused by unobserved factors. Therefore, residual difference indicates a wage gap due to discrimination. Quantity effect, in brief, is the difference caused by the change in the endowments inventory of the workforce. The price effect, on the other hand, is the effect of changes in the prices of those endowments in the labor market. For example, if we define the difference between the wages of two people working in different sectors who have the same education status, gender, age and marital status as the sector premium, the change in this premium and the premium itself shows the price effect. Regarding other abbreviations in the table, "E" stands for the change in expected difference and " $U$ " stands for the change in residuals.

It is observed that the raw difference decreased in the 2004-2017 period. This shows that the observed wage gap between men and women has narrowed. On the other hand, the increase in the residual difference from $18.2 \%$ to $23.1 \%$ indicates that the wage discrimination against women in the labor market has increased. The reason for the increase in the discrimination-based wage gap despite the narrowing gap observed is that the average level of education of women in the labor market has increased faster than men in the said period. As a matter of fact, Table 10 shows that the situation is caused by the quantity effect.

Table 9: Wage Gap Decomposition, Juhn-Murphy-Pierce Method

\begin{tabular}{rrrr}
\hline & Raw Differential & Quantity Effect & Residual Gap \\
\hline $\mathbf{2 0 0 4}$ & 0.179 & -0.003 & 0.182 \\
$\mathbf{2 0 1 7}$ & 0.147 & -0.084 & 0.231 \\
\hline
\end{tabular}

Table 10: Change in Wage Gap Decomposition, 2004-2017

\begin{tabular}{|c|c|c|c|}
\hline \multirow[b]{3}{*}{ Total } & \multicolumn{3}{|c|}{ Difference in (components of) differentials: } \\
\hline & D & $E$ & U \\
\hline & -0.032 & -0.082 & 0.050 \\
\hline \multicolumn{4}{|c|}{ Decomposition of difference in predicted gap: } \\
\hline & $E$ & $\mathbf{Q}$ & $\mathbf{P}$ \\
\hline \multirow[t]{3}{*}{ Total } & -0.082 & -0.065 & -0.016 \\
\hline & \multicolumn{3}{|c|}{ Decomposition of difference in residual gap: } \\
\hline & $\mathbf{U}$ & $\mathbf{Q}$ & $\mathbf{P}$ \\
\hline Total & 0.050 & 0.102 & -0.053 \\
\hline
\end{tabular}




\section{CONCLUSION}

In conclusion, it can be said that a significant portion of the gender wage gap in the period 2004-2017 is due to discrimination. In other words, the average wages of women must have been higher than that of the men when the endowments (such as human capital) are taken into consideration, but the final wage gap is getting wider in favor of men because of the discrimination against women in labor market. Last but not least, the data show that gender wage gap and discrimination based loss in female wages are seem to be persistent in Turkish labor market, but as the average level of female employees increase the gap is expected to decline in long run.

\section{REFERENCES}

Acker, J. (1991). Thinking about Wages: The gendered wage gap in Swedish banks. Gender and Society, Special Issue: Marxist Feminist Theory, 5 (3), 390-407.

Blinder, A. S. (1973). Wage discrimination: reduced form and structural estimates. The Journal of Human Resources, 8 (4), $436-455$.

Burnette, J. (1997). An investigation of the female-male wage gap during the industrial revolution in Britain. The Economic History Review, New Series, 50 (2), 257-281.

Cohen, P. N. and Huffman, M. L. (2007). Working for the woman? Female managers and the gender wage gap. American Sociological Review, 72 (5), 681-704.

Filer, R. K. (1985). Male-female wage differences: the ımportance of compensating differentials. Industrial and Labor Relations Review, 38 (3), 426-437.

Hersch, J. and Stratton, L. (1997). Housework, fixed effects, and wages of married workers. The Journal of Human Resources, 32 (2), 285307.

Juhn C., Murphy K. and Pierce B. (1991). Accounting for the slowdown in the black white wage convergence, in Kosters M. (Ed) Workers and their wages, 107-43, AEI Press.

Juhn C., Murphy K. and Pierce B. (1993). Wage inequality and the rise in returns to skill. Journal of Political Economy, 101 (3), $410-442$.

Juhn, C., Rubinstein, Y. and Zuppann, C. (2015). The quantity-quality trade-off and the formation of cognitive and non-cognitive skills. NBER Workıng Paper Series, 1-46.

Kumlin, J. (2007). The sex wage gap in Japan and Sweden: the role of human capital, workplace sex composition, and family responsibility. European Sociological Review, 23 (2), 203-221.

McCall, L. (1998). Spatial routes to gender wage (In)equality: regional restructuring and wage differentials by gender and education. Economic Geography, 74 (4), 379-404.

McCall, L. (2000). Gender and the new ınequality: explaining the college/non-college wage gap. American Sociological Review, 65 (2), $234-$ 255.

Oaxaca, R. L. (1973). Male-female wage differentials in urban labor markets. International Economic Review, 14 (3), $693-709$.

Oaxaca, R. L. (1975). Estimation of union/nonunion wage differentials within occupational/regional subgroups. The Journal of Human Resources, 10 (4), 529-537.

Pereira, J. and Galepo, A. (2007). Regional wage differantials: static and dynamic approaches. CEFAGE-UE Working Paper, 1-30.

Polavieja, J. G. (2005). Task specificity and the gender wage gap: theoretical considerations and empirical analysis of the Spanish Survey on Wage Structure. European Sociological Review, 21 (2), 165-181.

Wellington, A. J. (1993). Changes in the male/female wage gap, 1976-85. The Journal of Human Resources, 28 (2), $383-411$.

Tarımsal işletmelerde ücret yapısı. (2014). Ankara: Türkiye İstatistik Kurumu.

Türkiye İstatistik Kurumu. İşgücü İstatistikleri, Kasım 2015. http://www.tuik.gov.tr/HbGetirHTML.do?id=21576 (Date of access 15.02.2016) 